\title{
Acridinium Ester Chemiluminescence: Methyl Substitution on the Acridine Moiety
}

\author{
Manabu Nakazono ${ }^{1 *}$, Shinkoh Nanbu², Takeyuki Akita', and Kenji Hamase ${ }^{1}$ \\ ${ }^{1}$ Graduate School of Pharmaceutical Sciences, Kyushu University, 3-1-1 Maidashi, Higashi-ku, Fukuoka 812-8582, JAPAN \\ ${ }^{2}$ Faculty of Science and Technology, Sophia University, 7-1 Kioi-Cho, Chiyoda-ku, Tokyo 102-8554, JAPAN
}

\begin{abstract}
Methyl groups were introduced on the acridine moiety in chemiluminescent acridinium esters that have electron-withdrawing groups (trifluoromethyl, cyano, nitro, ethoxycarbonyl) at the 4-position on the phenyl ester. The introduction of methyl groups at the 2-, 2,7-, and 2,3,6,7-positions on the acridine moiety shifted the optimal $\mathrm{pH}$ that gave relatively strong chemiluminescence intensity from neutral conditions to alkaline conditions. 4-(Ethoxycarbonyl)phenyl 2,3,6,7,10-pentamethyl-10 $\lambda^{4}$-acridine-9carboxylate, trifluoromethanesulfonate salt showed long-lasting chemiluminescence under alkaline conditions. Acridinium esters to determine hydrogen peroxide concentration at $\mathbf{p H ~ 7 - 1 0}$ were newly developed.
\end{abstract}

Key words: methyl substitution, chemiluminescence, acridinium ester, $\mathrm{pH}$ shift, emission spectrum

\section{Introduction}

Chemiluminescence (CL) is light emission produced by chemical reaction. Most of the CL is associated with the oxidation reaction. Chemiluminescent compounds have been used for detection, measurement, sensor, and imaging of various analytes. In CL studies, novel properties and high sensitivity have attracted much attention. The synthesis of new CL compounds is crucial to discovering novel properties and achieving high sensitivity. Compounds with extremely strong CL intensity that provide unprecedented CL conditions could be useful for highly selective CL assays $^{1-7)}$. Acridinium ester and luminol derivatives are useful chemiluminescent compounds, and require the addition of a strong base and oxidant to produce strong CL intensity. Commonly, CL assays are not suitable as highly sensitive assays across a wide range of $\mathrm{pH}$ conditions, including neutral. In certain chemiluminescent compounds, therefore, it is useful to search for derivatizations that can shift the optimal pH on CL. In this investigation, we attempted to identify more facile substitution to give the optimal pH shift for the CL of acridinium ester derivatives.

Based on the possible CL mechanism of acridinium ester derivatives, acridinium ester derivatives react with hydrogen peroxide to produce 10-methyl-9 (10H)-acridone (CL species) via a dioxetanone, with a maxima emission wavelength of approximately $430 \mathrm{~nm}$ (Scheme 1). Various acridinium ester derivatives were synthesized and their photo- physical properties were investigated ${ }^{8-14)}$. Acridinium ester derivatives have been particularly useful compounds in CL enzyme immunoassays ${ }^{15-18)}$. We have recently clarified that acridinium ester derivatives having electron-withdrawing groups at the 4-position on the phenyl ester produced strong CL intensities at $\mathrm{pH} 7$ and $8^{19,20)}$. The CL intensity at higher $\mathrm{pH}$ (alkaline conditions) apparently decreased. Upon further investigations, methoxycarbonyl-phenyl 10-methyl$10 \lambda^{4}$-2,7-disubstituted acridine-9-carboxylate derivatives were synthesized and their CL were measured, and the introduction of methyl groups at the 2,7-positions on the acridine moiety was effective in increasing the CL intensities at $\mathrm{pH} 9$ and $10^{21)}$.

For our present purposes, we considered that the hydrolysis of phenyl ester in acridinium ester derivatives under alkaline conditions may be related to this experimental result $^{11,22,23)}$. Before the dioxetanone is produced, the hydrolysis of phenyl ester mainly proceeds and free carboxylic acid is formed (Scheme 1). Methyl substitutions on the acridine moiety could shift the optimal pH for the CL gradually from neutral conditions to alkaline conditions. Thus, the CL intensities of acridinium ester derivatives could be changed at different $\mathrm{pH}$ values by introducing different numbers of methyl groups on the acridine moiety.

Encouraged with these backgrounds, we introduced methyl groups at the 2-, 2,7- and 2,3,6,7-positions on the acridine moiety in acridinium ester derivatives with elec-

\footnotetext{
*Correspondence to: Manabu Nakazono, Graduate School of Pharmaceutical Sciences, Kyushu University, 3-1-1 Maidashi, Higashi-ku, Fukuoka 812-8582, JAPAN

E-mail: nakazono@phar.kyushu-u.ac.jp

Accepted July 8, 2021 (received for review June 6, 2021)

Journal of Oleo Science ISSN 1345-8957 print / ISSN 1347-3352 online

http://www.jstage.jst.go.jp/browse/jos/ http://mc.manusriptcentral.com/jjocs

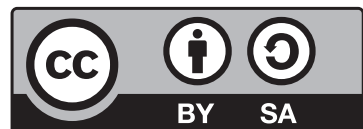




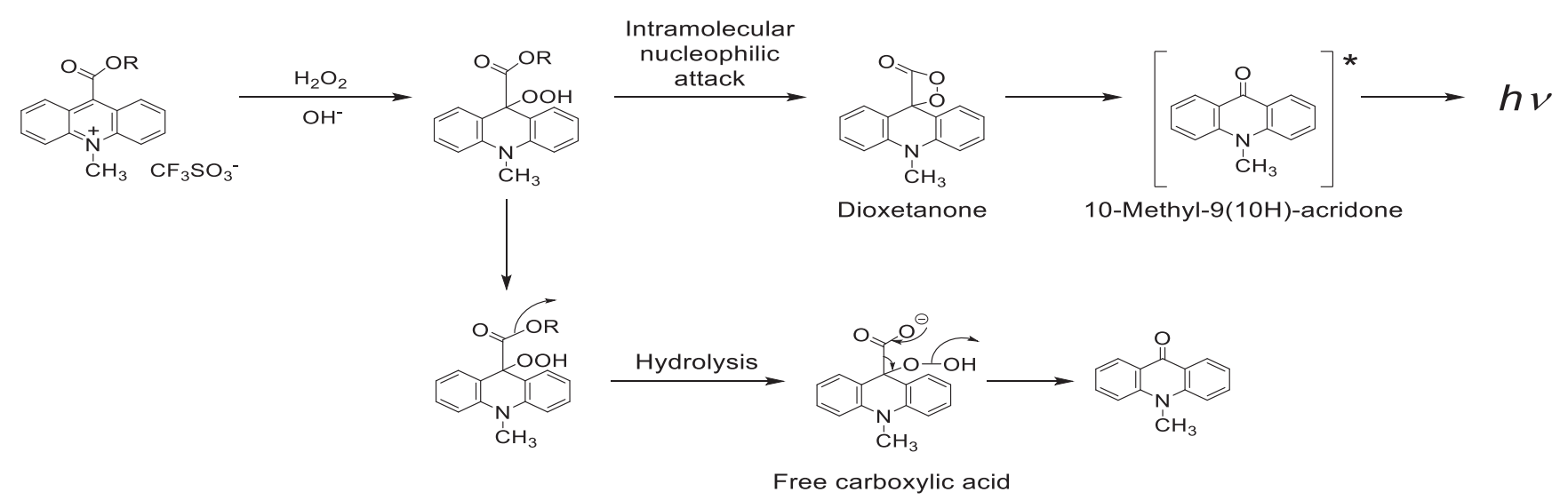

Scheme 1 Possible chemiluminescence mechanism of acridinium ester derivatives via dioxetanone formation, and hydrolysis of phenyl ester.<smiles>[R]c1ccc(OC(=O)c2c3ccccc3[n+](C)c3ccc(C)cc23)cc1</smiles>

\begin{tabular}{ccc}
\hline Compound & $\mathrm{R}$ & Yield [\%] \\
\hline 1a & $\mathrm{CF}_{3}$ & 54 \\
1b & $\mathrm{CN}$ & 49 \\
1c & $\mathrm{NO}_{2}$ & 65 \\
1d & $\mathrm{COOCH}_{2} \mathrm{CH}_{3}$ & 68 \\
\hline
\end{tabular}

tron-withdrawing groups (trifluoromethyl, cyano, nitro, ethoxycarbonyl)at the 4-position on the phenyl ester (Table 1). CL intensities and spectra were evaluated at $\mathrm{pH}$ $7-10$, and CL methods for measuring hydrogen peroxide at each $\mathrm{pH}$ value were developed.

\section{Materials and Methods}

\subsection{Materials}

General procedure for the synthesis of 1a-3d

To a solution of 2-methylacridine-9-carbonyl chloride (70 mg, $0.27 \mathrm{mmol}$ ), 2,7-dimethylacridine-9-carbonyl chloride (110 mg, $0.41 \mathrm{mmol}$ ), or 2,3,6,7-tetramethylacridine-9-carbonyl chloride $(70 \mathrm{mg}, 0.24 \mathrm{mmol})$ in dry dichloromethane $(5 \mathrm{~mL})$ was added 4-dimethylaminopyridine $(30 \mathrm{mg}, 0.25$ $\mathrm{mmol})$, the corresponding phenols $(0.54 \mathrm{mmol}$ or 0.48 $\mathrm{mmol})$, and triethylamine $(0.4 \mathrm{~mL})$. The mixture was stirred at ambient temperature overnight. Chloroform (80 $\mathrm{mL})$ and water $(60 \mathrm{~mL})$ were added to the solution. The organic layer was dried with anhydrous magnesium sulfate.
The filtrate was evaporated in vacuo, and the residue was purified by column chromatography (silica gel $60 \mathrm{~N}$ ) to produce the desired acridine-9-carboxylates. These were $N$-methylated by methyl trifluoromethanesulfonate in dichloromethane, and the desired acridine-9-carboxylates as trifluoromethanesulfonate salts were purified by column chromatography (silica gel, chloroform-methanol). Compounds $1 \mathrm{c}, 1 \mathrm{~d}$, and $2 \mathrm{a}-2 \mathrm{~d}$ were obtained after washing the resulting precipitate with diethyl ether.

4-(Trifluoromethane) phenyl 2,10-dimethyl-10 $\lambda^{4}$-acridine9-carboxylate, trifluoromethanesulfonate salt (1a).

$80 \mathrm{mg}\left(54 \%\right.$ yield). Yellow solid. M.p. $248-250^{\circ} \mathrm{C} .{ }^{1} \mathrm{H}$ $\operatorname{NMR}\left(500 \mathrm{MHz}, \mathrm{DMSO}-\mathrm{d}_{6}\right): \delta=2.76(\mathrm{~s}, 3 \mathrm{H}), 4.95(\mathrm{~s}, 3 \mathrm{H})$, $8.05(\mathrm{~s}, 4 \mathrm{H}), 8.15(\mathrm{t}, J=8 \mathrm{~Hz}, 1 \mathrm{H}), 8.37(\mathrm{~s}, 1 \mathrm{H}), 8.42(\mathrm{~d}, J=$ $10 \mathrm{~Hz}, 1 \mathrm{H}), 8.51(\mathrm{t}, J=10 \mathrm{~Hz}, 1 \mathrm{H}), 8.64(\mathrm{~d}, J=8.5 \mathrm{~Hz}, 1 \mathrm{H})$, $8.87(\mathrm{~d}, J=9 \mathrm{~Hz}, 1 \mathrm{H}), 8.92(\mathrm{~d}, J=9.5 \mathrm{~Hz}, 1 \mathrm{H}) .{ }^{13} \mathrm{C} \mathrm{NMR}$ $\left(125.7 \mathrm{MHz}\right.$, DMSO-d $\left.\mathrm{d}_{6}\right): \delta=21.4,120.2,120.3,122.9,123.1$, 123.6, 125.4, 127.8, 127.9, 130.2, 139, 141.1, 141.5, 141.7, 142.3, 152.8, 163.4. HR-MS $\left(\mathrm{FAB}^{+}\right)$calcd for $\mathrm{C}_{23} \mathrm{H}_{17} \mathrm{~F}_{3} \mathrm{NO}_{2}{ }^{+}$ 396.1211 $\left(\mathrm{M}^{+}\right)$found 396.1214. Anal calcd for $\mathrm{C}_{24} \mathrm{H}_{17} \mathrm{~F}_{6}$ 
$\mathrm{NO}_{5} \mathrm{~S}: \mathrm{C}, 52.85 ; \mathrm{H}, 3.14 ; \mathrm{N}, 2.57$ found: C, 52.34; H, 3.00; N, 2.53 .

4-Cyanophenyl 2,10-dimethyl-10 $\lambda^{4}$-acridine-9-carboxylate, trifluoromethanesulfonate salt $(\mathbf{1 b})$.

$67 \mathrm{mg}\left(49 \%\right.$ yield). Yellow solid. M.p. $285-288^{\circ} \mathrm{C} .{ }^{1} \mathrm{H}$ NMR $(500 \mathrm{MHz}$, DMSO-d 6 ) : $\delta=2.75(\mathrm{~s}, 3 \mathrm{H}), 4.95(\mathrm{~s}, 3 \mathrm{H})$, $8.04(\mathrm{~d}, J=9 \mathrm{~Hz}, 2 \mathrm{H}), 8.14(\mathrm{~m}, 3 \mathrm{H}), 8.36(\mathrm{~s}, 1 \mathrm{H}), 8.42(\mathrm{dd}, J$ $=1.5,9.5 \mathrm{~Hz}, 1 \mathrm{H}), 8.5(\mathrm{t}, J=9.5 \mathrm{~Hz}, 1 \mathrm{H}), 8.63(\mathrm{~d}, J=9 \mathrm{~Hz}$, $1 \mathrm{H}), 8.87(\mathrm{~d}, J=9.5 \mathrm{~Hz}, 1 \mathrm{H}), 8.91(\mathrm{~d}, J=9 \mathrm{~Hz}, 1 \mathrm{H}) .{ }^{13} \mathrm{C}$ $\operatorname{NMR}\left(125.7 \mathrm{MHz}\right.$, DMSO-d $\left.\mathrm{d}_{6}\right): \delta=21.4,110,111.1,118.5$, $120.1,120.3,123,123.1,123.9,125.4,127.8,130.2,135$, $139,141.1,141.5,141.7,142.3,145.2,153.2,163.3$. HR-MS $\left(\mathrm{FAB}^{+}\right.$) calcd for $\mathrm{C}_{23} \mathrm{H}_{17} \mathrm{~N}_{2} \mathrm{O}_{2}{ }^{+} 353.1290\left(\mathrm{M}^{+}\right)$found 353.1293. Anal calcd for $\mathrm{C}_{24} \mathrm{H}_{17} \mathrm{~F}_{3} \mathrm{~N}_{2} \mathrm{O}_{5} \mathrm{~S}$ : C, 57.37; H, 3.41; N, 5.58 found: C, $57.17 ; \mathrm{H}, 3.26 ; \mathrm{N}, 5.51$.

4-Nitrophenyl 2,10-dimethyl-10 $\lambda^{4}$-acridine-9-carboxylate, trifluoromethanesulfonate salt (1c).

$92 \mathrm{mg}\left(65 \%\right.$ yield). Yellow solid. M.p. $294-297^{\circ} \mathrm{C} .{ }^{1} \mathrm{H}$ $\operatorname{NMR}\left(500 \mathrm{MHz}\right.$, DMSO-d $\left._{6}\right): \delta=2.76(\mathrm{~s}, 3 \mathrm{H}), 4.95(\mathrm{~s}, 3 \mathrm{H})$, $8.1(\mathrm{~m}, 3 \mathrm{H}), 8.38(\mathrm{~s}, 1 \mathrm{H}), 8.42(\mathrm{~d}, J=10 \mathrm{~Hz}, 1 \mathrm{H}), 8.5(\mathrm{~m}$, $3 \mathrm{H}), 8.65(\mathrm{~d}, J=8 \mathrm{~Hz}, 1 \mathrm{H}), 8.87(\mathrm{~d}, J=9.5 \mathrm{~Hz}, 1 \mathrm{H}), 8.92(\mathrm{~d}$, $J=9.5 \mathrm{~Hz}, 1 \mathrm{H}) \cdot{ }^{13} \mathrm{C} \mathrm{NMR}\left(125.7 \mathrm{MHz}, \mathrm{DMSO}-\mathrm{d}_{6}\right): \delta=21.4$, $120.2,120.3,123,123.2,124,125.4,126.1,127.8,130.2$, 139.1, 141.1, 141.5, 141.8, 142.4, 145.1, 146.8, 154.4, 163.2 . HR-MS $\left(\mathrm{FAB}^{+}\right)$calcd for $\mathrm{C}_{22} \mathrm{H}_{17} \mathrm{~N}_{2} \mathrm{O}_{4}{ }^{+} 373.1188\left(\mathrm{M}^{+}\right)$found 373.1178. Anal calcd for $\mathrm{C}_{23} \mathrm{H}_{17} \mathrm{~F}_{3} \mathrm{~N}_{2} \mathrm{O}_{7} \mathrm{~S}$ : C, 52.88; H, 3.28; N, 5.36 found: C, 52.83; H, 3.27; N, 5.26.

4-(Ethoxycarbonyl) phenyl 2,10-dimethyl-10 $\lambda^{4}$-acridine-9carboxylate, trifluoromethanesulfonate salt (1d).

$87 \mathrm{mg}$ (68\% yield). Yellow solid. M.p. $268-270{ }^{\circ} \mathrm{C} .{ }^{1} \mathrm{H}$ $\operatorname{NMR}\left(500 \mathrm{MHz}, \mathrm{DMSO}-\mathrm{d}_{6}\right): \delta=1.36(\mathrm{t}, J=7.5 \mathrm{~Hz}, 3 \mathrm{H}), 2.76$ $(\mathrm{s}, 3 \mathrm{H}), 4.37$ (q, $J=7.5 \mathrm{~Hz}, 2 \mathrm{H}), 4.95(\mathrm{~s}, 3 \mathrm{H}), 7.94(\mathrm{~d}, J=9$ $\mathrm{Hz}, 2 \mathrm{H}), 8.15(\mathrm{~m}, 3 \mathrm{H}), 8.35(\mathrm{~s}, 1 \mathrm{H}), 8.42(\mathrm{~d}, J=9.5 \mathrm{~Hz}, 1 \mathrm{H})$, $8.51(\mathrm{t}, J=8.5 \mathrm{~Hz}, 1 \mathrm{H}), 8.61(\mathrm{~d}, J=8 \mathrm{~Hz}, 1 \mathrm{H}), 8.87(\mathrm{~d}, J=9$ $\mathrm{Hz}, 1 \mathrm{H}), 8.92(\mathrm{~d}, J=9.5 \mathrm{~Hz}, 1 \mathrm{H}) \cdot{ }^{13} \mathrm{C} \mathrm{NMR}(125.7 \mathrm{MHz}$, DMSO- $\left._{6}\right): \delta=14.6,21.4,61.6,120.2,120.3,122.8,123$, 123.1, 125.3, 127.7, 129.7, 130.2, 131.6, 139, 141.1, 141.5, $141.8,142.3,145.5,153.5,163.4,165.4 . \mathrm{HR}-\mathrm{MS}\left(\mathrm{FAB}^{+}\right)$ calcd for $\mathrm{C}_{25} \mathrm{H}_{22} \mathrm{NO}_{4}{ }^{+} 400.1549\left(\mathrm{M}^{+}\right)$found 400.1533. Anal calcd for $\mathrm{C}_{26} \mathrm{H}_{22} \mathrm{~F}_{3} \mathrm{NO}_{7} \mathrm{~S}$ : C, 56.83; H, 4.04; N, 2.55 found: C, $56.07 ; \mathrm{H}, 3.84 ; \mathrm{N}, 2.45$.

4-(Trifluoromethyl) phenyl 2,7,10-trimethyl-10 $\lambda^{4}$-acridine9-carboxylate, trifluoromethanesulfonate $\operatorname{salt}(2 \mathrm{a})$.

$80 \mathrm{mg}(39 \%$ yield $)$. Yellow solid. M.p. $249-252^{\circ} \mathrm{C} .{ }^{1} \mathrm{H}$ $\operatorname{NMR}\left(500 \mathrm{MHz}, \mathrm{DMSO}_{6}\right): \delta=2.73(\mathrm{~s}, 6 \mathrm{H}), 4.91(\mathrm{~s}, 3 \mathrm{H})$, $8.03(\mathrm{~s}, 4 \mathrm{H}), 8.29(\mathrm{~s}, 2 \mathrm{H}), 8.35(\mathrm{~d}, J=9.5 \mathrm{~Hz}, 2 \mathrm{H}), 8.82(\mathrm{~d}, J$ $=9.5 \mathrm{~Hz}, 2 \mathrm{H}) \cdot{ }^{13} \mathrm{C}$ NMR $\left(125.7 \mathrm{MHz}\right.$, DMSO $\left.\mathrm{d}_{6}\right): \delta=21.4$, 120.1, 123.2, 123.6, 125.2, 127.9, 140.8, 140.9, 141.7, 144.1, 152.8, 163.4. HR-MS $\left(\mathrm{FAB}^{+}\right)$calcd for $\mathrm{C}_{24} \mathrm{H}_{19} \mathrm{~F}_{3} \mathrm{NO}_{2}{ }^{+}$ 410.1368 $\left(\mathrm{M}^{+}\right)$found 410.1366. Anal calcd for $\mathrm{C}_{25} \mathrm{H}_{19} \mathrm{~F}_{6}$
$\mathrm{NO}_{5} \mathrm{~S}: \mathrm{C}, 53.67 ; \mathrm{H}, 3.42 ; \mathrm{N}, 2.50$ found: C, 51.97; H, 3.41; N, 2.46 .

4-Cyanophenyl 2,7,10-trimethyl- $10 \lambda^{4}$-acridine-9carboxylate, trifluoromethanesulfonate salt (2b).

$80 \mathrm{mg}(40 \%$ yield $)$. Yellow solid. M.p. $273-276{ }^{\circ} \mathrm{C} .{ }^{1} \mathrm{H}$ NMR $\left(500 \mathrm{MHz}, \mathrm{DMSO}-\mathrm{d}_{6}\right): \delta=2.72(\mathrm{~s}, 6 \mathrm{H}), 4.91(\mathrm{~s}, 3 \mathrm{H})$, $8.02(\mathrm{~d}, J=9 \mathrm{~Hz}, 2 \mathrm{H}), 8.15(\mathrm{~d}, J=8.5 \mathrm{~Hz}, 2 \mathrm{H}), 8.29$ (s, 2H), $8.35(\mathrm{dd}, J=1.5,9.5 \mathrm{~Hz}, 2 \mathrm{H}), 8.81(\mathrm{~d}, J=9.5 \mathrm{~Hz}, 2 \mathrm{H}) \cdot{ }^{13} \mathrm{C}$ $\operatorname{NMR}(125.7 \mathrm{MHz}$, DMSO-d 6 ): $\delta=21.4,111,118.5,120.1$, 123.2, 123.9, 125.2, 135, 140.7, 141, 141.7, 143.9, 153.2, 163.3. HR-MS $\left(\mathrm{FAB}^{+}\right)$calcd for $\mathrm{C}_{24} \mathrm{H}_{19} \mathrm{~N}_{2} \mathrm{O}_{2}{ }^{+} 367.1447\left(\mathrm{M}^{+}\right)$ found 367.1447. Anal calcd for $\mathrm{C}_{25} \mathrm{H}_{19} \mathrm{~F}_{3} \mathrm{~N}_{2} \mathrm{O}_{5} \mathrm{~S}$ : C, 58.14; H, $3.71 ; \mathrm{N}, 5.42$ found: C, 57.72; H, 3.70; N, 5.65.

4-Nitrophenyl 2,7,10-trimethyl-10 $\lambda^{4}$-acridine-9carboxylate, trifluoromethanesulfonate salt $(2 \mathrm{c})$.

$110 \mathrm{mg}(52 \%$ yield $)$. Yellow solid. M.p. $276-279^{\circ} \mathrm{C} .{ }^{1} \mathrm{H}$ $\operatorname{NMR}\left(500 \mathrm{MHz}\right.$, DMSO-d $\left.\mathrm{d}_{6}\right): \delta=2.73(\mathrm{~s}, 6 \mathrm{H}), 4.92(\mathrm{~s}, 3 \mathrm{H})$, $8.08(\mathrm{~d}, J=8.5 \mathrm{~Hz}, 2 \mathrm{H}), 8.31(\mathrm{~s}, 2 \mathrm{H}), 8.36(\mathrm{dd}, J=1.5,9.5$ $\mathrm{Hz}, 2 \mathrm{H}), 8.48(\mathrm{~d}, J=9.5 \mathrm{~Hz}, 2 \mathrm{H}), 8.82(\mathrm{~d}, J=9.5 \mathrm{~Hz}, 2 \mathrm{H})$. ${ }^{13} \mathrm{C}$ NMR $\left(125.7 \mathrm{MHz}\right.$, DMSO-d $\left.{ }_{6}\right): \delta=21.4,120.1,123.2,124$, 125.2, 126.1, 140.7, 141, 141.7, 143.8, 146.7, 154.4, 163.2. HR-MS $\left(\mathrm{FAB}^{+}\right.$) calcd for $\mathrm{C}_{23} \mathrm{H}_{19} \mathrm{~N}_{2} \mathrm{O}_{4}{ }^{+} 387.1345\left(\mathrm{M}^{+}\right)$found 387.1345. Anal calcd for $\mathrm{C}_{24} \mathrm{H}_{19} \mathrm{~F}_{3} \mathrm{~N}_{2} \mathrm{O}_{7} \mathrm{~S}$ : C, 53.73; H, 3.57; N, 5.22 found: C, 53.36; H, 3.61; N, 5.09.

4-(Ethoxycarbonyl) phenyl 2,7,10-trimethyl-10 $\lambda^{4}$-acridine9-carboxylate, trifluoromethanesulfonate salt $(2 \mathrm{~d})$.

$90 \mathrm{mg}$ ( $40 \%$ yield). Yellow solid. M.p. $296-298^{\circ} \mathrm{C} .{ }^{1} \mathrm{H}$ $\operatorname{NMR}\left(500 \mathrm{MHz}\right.$, DMSO-d $\left.\mathrm{d}_{6}\right): \delta=1.34(\mathrm{t}, J=7 \mathrm{~Hz}, 3 \mathrm{H}), 2.73$ $(\mathrm{s}, 6 \mathrm{H}), 4.35(\mathrm{q}, J=7 \mathrm{~Hz}, 2 \mathrm{H}), 4.91(\mathrm{~s}, 3 \mathrm{H}), 7.91(\mathrm{~d}, J=8.5$ $\mathrm{Hz}, 2 \mathrm{H}), 8.19(\mathrm{~d}, J=9 \mathrm{~Hz}, 2 \mathrm{H}), 8.27$ (s, 2H), $8.35(\mathrm{dd}, J=2$, $10 \mathrm{~Hz}, 2 \mathrm{H}), 8.82(\mathrm{~d}, J=10 \mathrm{~Hz}, 2 \mathrm{H}) \cdot{ }^{13} \mathrm{C} \operatorname{NMR}(125.7 \mathrm{MHz}$, DMSO- $\left._{6}\right): \delta=14.6,21.4,61.6,120.1,122.9,123.1,125.1$, 129.5, 131.6, 140.7, 140.9, 141.6, 144.1, 153.4, 163.5, 165.4. HR-MS $\left(\mathrm{FAB}^{+}\right.$) calcd for $\mathrm{C}_{26} \mathrm{H}_{24} \mathrm{NO}_{4}{ }^{+} 414.1705\left(\mathrm{M}^{+}\right)$found 414.1705. Anal calcd for $\mathrm{C}_{27} \mathrm{H}_{24} \mathrm{~F}_{3} \mathrm{NO}_{7} \mathrm{~S}$ : C, 57.55; H, 4.29; N, 2.49 found: C, 56.90; H, 4.33; N, 2.83 .

4-(Trifluoromethyl) phenyl 2,3,6,7,10-pentamethyl- $10 \lambda^{4}$ acridine-9-carboxylate, trifluoromethanesulfonate salt (3a).

$78 \mathrm{mg}\left(56 \%\right.$ yield). Yellow solid. M.p. $290-293^{\circ} \mathrm{C} .{ }^{1} \mathrm{H}$ $\operatorname{NMR}\left(500 \mathrm{MHz}, \mathrm{DMSO}-\mathrm{d}_{6}\right): \delta=2.63(\mathrm{~s}, 6 \mathrm{H}), 2.73(\mathrm{~s}, 6 \mathrm{H})$, $4.83(\mathrm{~s}, 3 \mathrm{H}), 8.01(\mathrm{~s}, 4 \mathrm{H}), 8.22(\mathrm{~s}, 2 \mathrm{H}), 8.67(\mathrm{~s}, 2 \mathrm{H}) .{ }^{13} \mathrm{C}$ NMR $\left(125.7 \mathrm{MHz}\right.$, acetone- $\left.\mathrm{d}_{6}\right): \delta=19,21.1,39,118.5$, $121.5,122.9,124.3,125.5,127.4,140.8,140.9,143.8,152.5$, 163.2. HR-MS $\left(\mathrm{FAB}^{+}\right)$calcd for $\mathrm{C}_{26} \mathrm{H}_{23} \mathrm{~F}_{3} \mathrm{NO}_{2}{ }^{+} 438.1681\left(\mathrm{M}^{+}\right)$ found 438.1681. Anal calcd for $\mathrm{C}_{27} \mathrm{H}_{23} \mathrm{~F}_{6} \mathrm{NO}_{5} \mathrm{~S}$ : C, 55.20; H, $3.95 ; \mathrm{N}, 2.38$ found: C, 54.83; H, 3.94; N, 2.39 .

4-Cyanophenyl 2,3,6,7,10-pentamethyl-10 $\lambda^{4}$-acridine-9carboxylate, trifluoromethanesulfonate salt (3b).

$64 \mathrm{mg}\left(50 \%\right.$ yield). Yellow solid. M.p. $266-269^{\circ} \mathrm{C} .{ }^{1} \mathrm{H}$ 
$\operatorname{NMR}\left(500 \mathrm{MHz}, \mathrm{DMSO}-\mathrm{d}_{6}\right): \delta=2.62(\mathrm{~s}, 6 \mathrm{H}), 2.72(\mathrm{~s}, 6 \mathrm{H})$, $4.83(\mathrm{~s}, 3 \mathrm{H}), 8(\mathrm{~d}, J=8.5 \mathrm{~Hz}, 2 \mathrm{H}), 8.14(\mathrm{~d}, J=9 \mathrm{~Hz}, 2 \mathrm{H})$, $8.21(\mathrm{~s}, 2 \mathrm{H}), 8.67(\mathrm{~s}, 2 \mathrm{H}) .{ }^{13} \mathrm{C} \mathrm{NMR}\left(125.7 \mathrm{MHz}, \mathrm{DMSO}-\mathrm{d}_{6}\right)$ : $\delta=19.8,21.9,110.9,118.6,119,121.3,124,125.4,135$, $135.2,140.6,140.9,142.8,152.1,153.1,163.4 . \mathrm{HR}-\mathrm{MS}\left(\mathrm{FAB}^{+}\right)$ calcd for $\mathrm{C}_{26} \mathrm{H}_{23} \mathrm{~N}_{2} \mathrm{O}_{2}{ }^{+} 395.1760\left(\mathrm{M}^{+}\right)$found 395.1757. Anal calcd for $\mathrm{C}_{27} \mathrm{H}_{23} \mathrm{~F}_{3} \mathrm{~N}_{2} \mathrm{O}_{5} \mathrm{~S}$ : C, 59.55; $\mathrm{H}, 4.26 ; \mathrm{N}, 5.14$ found: C, $59.04 ; \mathrm{H}, 4.25 ; \mathrm{N}, 5.13$.

4-Nitrophenyl 2,3,6,7,10-pentamethyl-10 $\lambda^{4}$-acridine-9carboxylate, trifluoromethanesulfonate salt (3c).

$65 \mathrm{mg}\left(49 \%\right.$ yield). Yellow solid. M.p. $267-270^{\circ} \mathrm{C} .{ }^{1} \mathrm{H}$ $\operatorname{NMR}\left(500 \mathrm{MHz}, \mathrm{DMSO}-\mathrm{d}_{6}\right): \delta=2.62(\mathrm{~s}, 6 \mathrm{H}), 2.73(\mathrm{~s}, 6 \mathrm{H})$, $4.83(\mathrm{~s}, 3 \mathrm{H}), 8.06$ (d, $J=9.5 \mathrm{~Hz}, 2 \mathrm{H}), 8.23(\mathrm{~s}, 2 \mathrm{H}), 8.47$ (d, $J$ $=9 \mathrm{~Hz}, 2 \mathrm{H}), 8.67(\mathrm{~s}, 2 \mathrm{H}) \cdot{ }^{13} \mathrm{C} \mathrm{NMR}\left(125.7 \mathrm{MHz}, \mathrm{DMSO}-\mathrm{d}_{6}\right)$ : $\delta=19.8,21.9,119,121.3,124,125.4,126,126.1,140.6$, $140.9,142.7,146.6,152.1,154.4,163.3 . \mathrm{HR}-\mathrm{MS}\left(\mathrm{FAB}^{+}\right)$ calcd for $\mathrm{C}_{25} \mathrm{H}_{23} \mathrm{~N}_{2} \mathrm{O}_{4}{ }^{+} 415.1658\left(\mathrm{M}^{+}\right)$found 415.1660. Anal calcd for $\mathrm{C}_{26} \mathrm{H}_{23} \mathrm{~F}_{3} \mathrm{~N}_{2} \mathrm{O}_{7} \mathrm{~S}$ : C, 55.32; H, 4.11; N, 4.96 found: C, 54.60; H, 4.07; N, 4.87 .

4-(Ethoxycarbonyl) phenyl 2,3,6,7,10-pentamethyl-10 $\lambda^{4}$ acridine-9-carboxylate, trifluoromethanesulfonate salt (3d).

$85 \mathrm{mg}\left(65 \%\right.$ yield). Yellow solid. M.p. $270-273{ }^{\circ} \mathrm{C} .{ }^{1} \mathrm{H}$ $\operatorname{NMR}\left(500 \mathrm{MHz}, \mathrm{DMSO}-\mathrm{d}_{6}\right): \delta=1.34(\mathrm{t}, J=7 \mathrm{~Hz}, 3 \mathrm{H}), 2.63$ $(\mathrm{s}, 6 \mathrm{H}), 2.73(\mathrm{~s}, 6 \mathrm{H}), 4.35(\mathrm{q}, J=6.5 \mathrm{~Hz}, 2 \mathrm{H}), 4.83(\mathrm{~s}, 3 \mathrm{H})$, $7.89(\mathrm{~d}, J=9 \mathrm{~Hz}, 2 \mathrm{H}), 8.18(\mathrm{~d}, J=9 \mathrm{~Hz}, 2 \mathrm{H}), 8.2(\mathrm{~s}, 2 \mathrm{H})$, $8.67(\mathrm{~s}, 2 \mathrm{H}) .{ }^{13} \mathrm{C} \mathrm{NMR}\left(125.7 \mathrm{MHz}, \mathrm{DMSO}-\mathrm{d}_{6}\right): \delta=14.6,19.8$, $21.9,61.6,119,121.3,122.9,125.3,129.4,131.6,140.7$, 140.9, 143.1, 152.1, 153.4, 163.6, 165.3. HR-MS $\left(\mathrm{FAB}^{+}\right)$calcd for $\mathrm{C}_{28} \mathrm{H}_{28} \mathrm{NO}_{4}{ }^{+} 442.2018\left(\mathrm{M}^{+}\right)$found 442.2018. Anal calcd for $\mathrm{C}_{29} \mathrm{H}_{28} \mathrm{~F}_{3} \mathrm{NO}_{7} \mathrm{~S}$ : C, 58.88; H, 4.77; N, 2.37 found: C, 58.42; $\mathrm{H}, 4.78 ; \mathrm{N}, 2.31$.

\subsection{Apparatus}

The ${ }^{1} \mathrm{H}$ NMR (500 MHz) and ${ }^{13} \mathrm{C} \mathrm{NMR}(125.7 \mathrm{MHz})$ spectra were obtained using an Inova-500 NMR (Agilent, Santa Clara, CA, USA) spectrometer. High resolution (HR) FAB-MS (positive) spectra were obtained using a JMSHX110A (JEOL, Tokyo, Japan) mass spectrometer. Column chromatography was performed with silica gel $60 \mathrm{~N}$ (spherical, neutral 40-50 $\mu \mathrm{m})$. Chemiluminescence was measured using a Lumat LB 9507 (Berthold, Bad Wildbad, Germany) luminometer, and CL spectra were recorded using a FP-6500 (JASCO, Tokyo, Japan) fluorometer.

\subsection{Chemiluminescence measurement}

To $50 \mu \mathrm{L}$ of a $10 \mathrm{nM}$ solution of $1 \mathrm{a}-3 \mathrm{~d}$ in dimethyl sulfoxide was added $100 \mu \mathrm{L}$ of a buffer solution (100 mM tris (hydroxymethyl) aminomethane hydrochloride(Tris-HCl) for $\mathrm{pH} 7$ and $\mathrm{pH}$ 8, $100 \mathrm{mM}$ glycine sodium hydroxide(Gly$\mathrm{NaOH}$ ) for $\mathrm{pH} 9$ and $\mathrm{pH} 10$ ). The mixture was allowed to stand for $20 \mathrm{~s}$, and then the CL reaction was initiated by adding $100 \mu \mathrm{L}$ of $1 \mathrm{mM}$ aqueous hydrogen peroxide solu- tion to the luminometer using an automatic injection system. The relative light unit integrated for 1 min was used to evaluate the CL intensity.

\subsection{Chemiluminescence spectra measurement}

To $0.5 \mathrm{~mL}$ of a $0.1 \mathrm{mM}$ solution of $1 \mathrm{a}, 2 \mathrm{a}$, and $3 \mathrm{~b}$ in dimethyl sulfoxide in a quartz cell $(10 \times 10 \times 50 \mathrm{~mm})$ was added $1 \mathrm{~mL}$ of a buffer solution (100 mM Tris-HCl for $\mathrm{pH} 7$ and $\mathrm{pH}$ 8, $100 \mathrm{mM}$ Gly-NaOH for $\mathrm{pH} 9$ and $\mathrm{pH} 10)$. The mixture was allowed to stand for $20 \mathrm{~s}$, and then the CL reaction was initiated by adding $1 \mathrm{~mL}$ of $100 \mathrm{mM}$ aqueous hydrogen peroxide solution. After $1 \mathrm{~min}$, the mixture was placed in a spectrometer (fluorescence bandwidth: $10 \mathrm{~nm}$; response: $0.5 \mathrm{~s}$; scanning speed: $500 \mathrm{~nm} / \mathrm{min}$ ) and the CL spectra was measured.

\subsection{Determination of hydrogen peroxide concentration}

To $50 \mu \mathrm{L}$ of a $10 \mathrm{nM}$ solution of $1 \mathrm{a}, 3 \mathrm{~b}$, and $3 \mathrm{~d}$ in dimethyl sulfoxide was added $100 \mu \mathrm{L}$ of a buffer solution $(100 \mathrm{mM}$ Tris-HCl for $\mathrm{pH} 7$ and $\mathrm{pH}$ 8; $100 \mathrm{mM}$ Gly-NaOH for $\mathrm{pH} 9$ and $\mathrm{pH} 10$ ). The mixture was allowed to stand for $20 \mathrm{~s}$, and then the CL reaction was initiated by adding $100 \mu \mathrm{L}$ of 0.01-1 mM aqueous hydrogen peroxide solution to the luminometer using an automatic injection system. The relative light unit integrated for 1 min were used to evaluate the CL intensity.

\section{Results and Discussion}

Compounds 1a-3d were new acridinium ester derivatives. Synthetic procedure of 1a-3d was shown in Scheme 2. 4-Methyl- $N$-phenylaniline, di- $p$-tolylamine or bis (3,4-dimethylphenyl) amine was used as a starting material. These starting materials with oxalyl dichloride and alminium chloride give isatin derivatives. The acridine ring was formed from an isatin structure in aqueous potassium hydoxide solution. The acridine derivatives were converted to acid chloride. Subsequently, esterification of phenols in the presence of 4-dimethylaminopyridine and triethylamine, and $\mathrm{N}$-methylation of acridine using methyl trifluoromethanesulfonate proceeded in dichloromethane. The yields for 1a-3d were $39 \%-68 \%$.

In CL measurements, to the solution of 1a-3d in dimethyl sulfoxide was added a buffer solution, and then aqueous hydrogen peroxide solution was added to the mixture. The CL emission was measured using luminometer. The timecourses for CL development of $1 \mathrm{~d}$ at $\mathrm{pH}$ 7-10 are shown in Fig. 1a. After the addition of hydrogen peroxide, the CL was flash-type and glow-type at $\mathrm{pH} 7$ and $\mathrm{pH} 8$, respectively. At $\mathrm{pH} 7$, the intramolecular nucleophilic attack of $\mathrm{OOH}$ at the 9-postion on the acridine moiety to the phenyl ester may rapidly occur (Scheme 1). CL intensities at $\mathrm{pH} 7$ and 8 were stronger than those at $\mathrm{pH} 9$ and 10. At $\mathrm{pH} 8$, the 


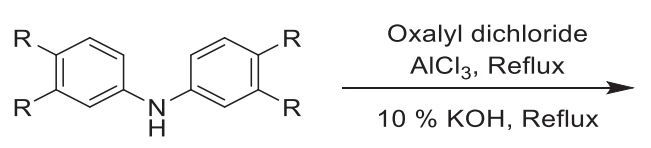<smiles>[R]c1cc2nc3cc([R])c([R])cc3c(C(=O)O)c2cc1[R]</smiles>

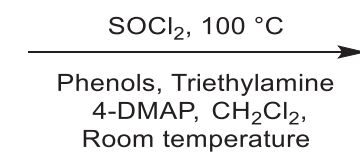<smiles>[R]c1ccc(OC(=O)c2c3ccc([R])cc3nc3cc([R])c([R])cc23)cc1</smiles>

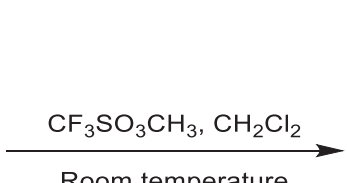<smiles>[R]c1ccc(OC(=O)c2c3cc([R])c([R])cc3[n+](C)c3cc([R])c([R])cc23)cc1</smiles>

Scheme 2 Synthetic procedure of 1a-3d.

(a)

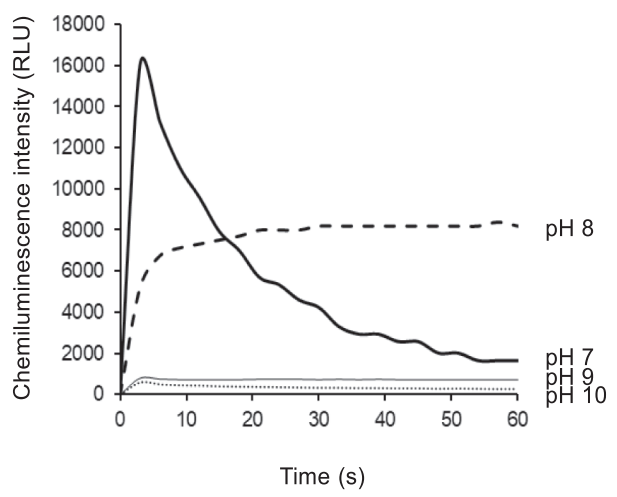

(b)

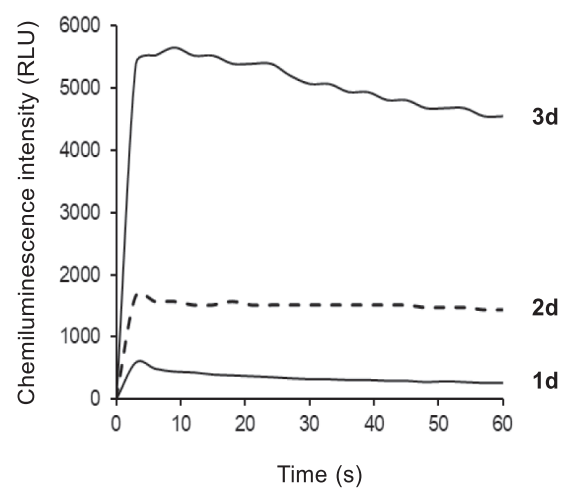

Fig. 1 (a) Time-course of the chemiluminescence development of $1 \mathrm{~d}$ at $\mathrm{pH}$ 7-10. (b) Time-course of the chemiluminescence development of $\mathbf{1 d}, \mathbf{2 d}$, and $\mathbf{3 d}$ at $\mathrm{pH} 10$. The concentration of $\mathbf{1 d}, \mathbf{2 d}$, and $\mathbf{3 d}$ was 10 nM. The concentration of hydrogen peroxide was $1 \mathrm{mM}$.

time required to reach the maximum relative light units (RLU) was approximately $30 \mathrm{~s}$ after the addition of hydrogen peroxide. The time-courses of the CL development of $1 \mathrm{a}$ and $1 \mathrm{~d}$ were similar at $\mathrm{pH} 7-10$. Fig. $1 \mathrm{~b}$ shows the timecourses of the CL development of $1 d, 2 d$, and $3 d$ at $\mathrm{pH} 10$. The descending order of CL intensities was as follows: $3 d$ $>2 d>1 d$. Thus, an increased number of methyl groups on the acridine moiety caused an increase of CL intensities under alkaline conditions. Interestingly, an acridinium ester that showed long-lasting CL was found, i.e., 3d.

The CL intensities of $1 \mathrm{a}-3 \mathrm{~d}$ at $\mathrm{pH}$ 7-10 are shown in Fig. 2. Dramatic change of CL intensities was observed at different $\mathrm{pH}$ values. The optimal $\mathrm{pH}$ value was defined as $\mathrm{pH}$ value that gave maximum CL intensity. The optimal $\mathrm{pH}$ values for the CL of $1 \mathrm{a}-1 \mathrm{~d}, \mathbf{2 a - 2 d}$, and $3 \mathrm{a}-3 \mathrm{~d}$ were $\mathrm{pH} 8$, $\mathrm{pH} 8-9$, and $\mathrm{pH} 9$, respectively. The optimal $\mathrm{pH}$ value for CL shifted from neutral conditions to alkaline conditions. The introduction of methyl groups (weak electron-donating groups) at the 2-, 2,7- and 2,3,6,7-positions on the acridine moiety affected the optimal $\mathrm{pH}$ value for the CL of $1 \mathrm{a}-3 \mathrm{~d}$. As shown in Fig. 2, the CL intensities of 1a-1d decreased apparently at $\mathrm{pH}$ 9-10. For example, the CL intensity of 1d at $\mathrm{pH} 8$ was approximately 11 -fold stronger than that at $\mathrm{pH}$
9. Relative to the CL intensities of $1 \mathrm{a}-1 \mathrm{~d}$ at $\mathrm{pH} 7-10$, the CL intensities of 2a-2d were higher at $\mathrm{pH}$ 9-10 and lower at $\mathrm{pH}$ 7-8. In particular, the increase of CL intensity at $\mathrm{pH}$ 9 was noticeable. Similar results were obtained for the CL intensities of $3 a-3 d$, with the CL intensities of $3 a-3 d$ at $\mathrm{pH}$ 10 being strong. The CL intensities of $3 a-3 d$ at $\mathrm{pH} 10$ were approximately 9-, 9-, 8-, and 15-fold stronger, respectively, than those of $1 \mathrm{a}-1 \mathrm{~d}$ at $\mathrm{pH} 10$. Among several CL compounds, luminol (5-amino-2,3-dihydrophthalazine-1,4-dione) has high CL intensities under alkaline conditions. When the concentrations of sodium hydroxide and hydrogen peroxide were $1 \mathrm{mM}$, the maximum CL intensity of 10 nM luminol was obtained. Compared to the CL intensities of $3 d(10 \mathrm{nM})$ and luminol (10 nM), those of $3 d$ at $\mathrm{pH} 9$ and 10 were approximately 4 -fold stronger than that of luminol.

In $1 \mathrm{a}-1 \mathrm{~d}$ at $\mathrm{pH}$ 9-10, after the hydroperoxide anion reacts with the carbon at the 9-position on the acridine moiety, the hydrolysis of phenyl ester may proceed $(\text { Scheme } 1)^{11,22,23)}$. In contrast, in 2a-3d at pH 9-10, the dioxetanone structure could mainly be formed as a chemiluminescent pathway, and the CL intensities increase. The introduction of methyl groups on the acridine moiety may suppress the hydrolysis of the phenyl ester in acridinium 


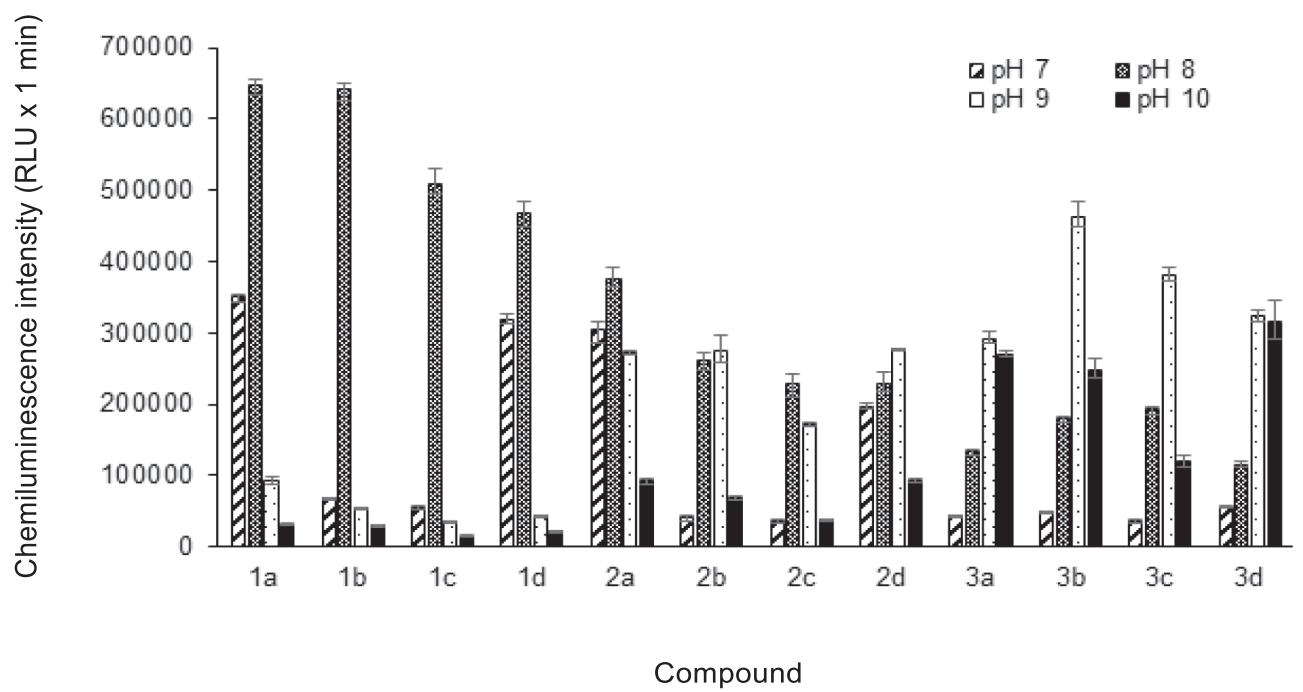

Fig. 2 Chemiluminescence intensities of $1 \mathrm{a}-3 \mathrm{~d}$ at $\mathrm{pH} 7-10$. The concentration of $1 \mathrm{a}-3 \mathrm{~d}$ and hydrogen peroxide was 10 nM and $1 \mathrm{mM}$, respectively. The relative light unit(RLU)integrated for 1 min was used to evaluate the chemiluminescence intensity.

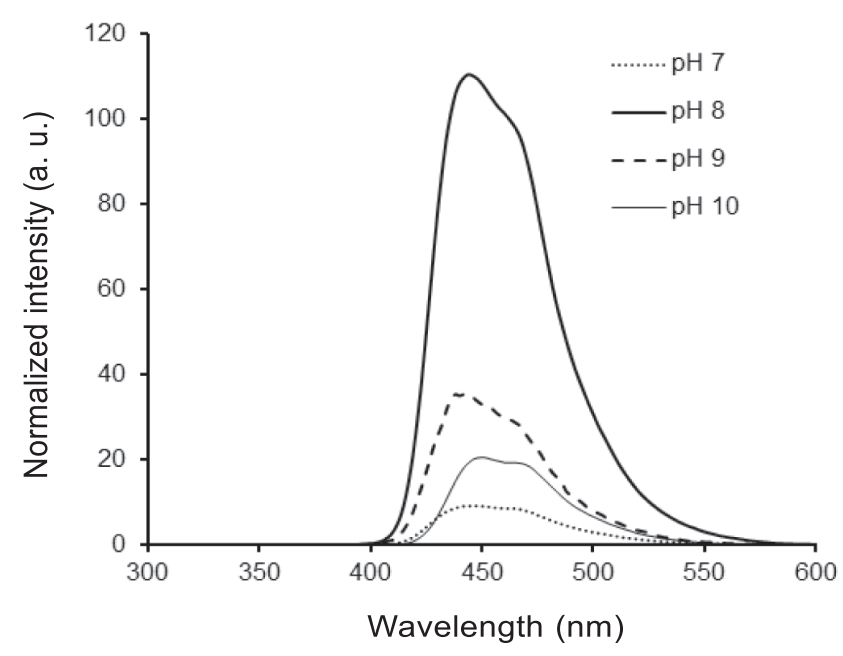

Fig. 3 Chemiluminescence spectra of $3 b$ at $\mathrm{pH} 7-10$. The concentration of $3 \mathrm{~b}$ and hydrogen peroxide was 0.1 $\mathrm{mM}$ and $100 \mathrm{mM}$, respectively.

ester derivatives.

Compounds $1 \mathrm{a}, 2 \mathrm{a}$, and $3 \mathrm{~b}$ were selected for the measurement of CL spectra, because these three had the strongest CL intensities among 1a-1d, 2a-2d, and 3a-3d, respectively. The CL spectra of $1 \mathrm{a}, 2 \mathrm{a}$, and $3 \mathrm{~b}$ were measured at $\mathrm{pH} 7-10$. The maxima wavelengths of CL emission of 3b were approximately 440-450 nm(Fig. 3). The maximum wavelengths of CL emission of $1 \mathrm{a}$ and $2 \mathrm{a}$ was similar with that of $3 b$ (Fig. S1). There was no apparent change in the maxima wavelengths with increasing number of methyl groups.

Acridinium ester derivatives synthesized in this study were applied to determine hydrogen peroxide concentra- tion at a wide range of $\mathrm{pH}$ conditions, including neutral. From the CL measurement of 1a-3d at pH 7-10, the CL intensities of $1 \mathrm{a}$ were maximal at $\mathrm{pH} 7$ and 8 . Compounds $3 \mathrm{~b}$ and $3 \mathrm{~d}$ gave maximum CL intensities at $\mathrm{pH} 9$ and $\mathrm{pH}$ 10, respectively. Therefore, hydrogen peroxide was measured using $1 \mathrm{a}, 3 \mathrm{~b}$ and $3 \mathrm{~d}$. Standard curve of hydrogen peroxide using $3 \mathrm{~d}$ at $\mathrm{pH} 10$ is shown in Fig. S2. The linear calibration ranges of hydrogen peroxide were $0.05-1 \mathrm{mM}(\mathrm{R}=$ 0.994) at $\mathrm{pH} 7$ and $0.01-1 \mathrm{mM}(\mathrm{R}=0.999)$ at $\mathrm{pH} 8$ using 1a (Fig. S2). The linear calibration ranges of hydrogen peroxide were $0.01-1 \mathrm{mM}(\mathrm{R}=0.999)$ at $\mathrm{pH} 9$ using $3 \mathrm{~b}$ (Fig. S2) and $0.01-1 \mathrm{mM}(\mathrm{R}=0.999)$ at $\mathrm{pH} 10$ using $3 \mathrm{~d}$. A relatively long range of detectability and good linearities $(R>0.994)$ were obtained. The detection limit (defined as the mean value of blank $+5 \sigma$ (standard deviation)) of hydrogen peroxide at pH 10 using $3 \mathrm{~d}$ was $4.5 \mathrm{mM}$. This CL method showed highly sensitive detection of hydrogen peroxide without an addition of catalyst. Compared to previous CL methods with an addition of catalyst for determining hydrogen peroxide using luminol hybrid $\mathrm{Mg}-\mathrm{Al}-\mathrm{CO}_{3}$ layered double oxides ${ }^{24)}$, CL energy transfer by luminol-CdTe quantum $\operatorname{dots}^{25)}$, luminol- $\mathrm{H}_{2} \mathrm{O}_{2}$ CL system using nanoparticles $\left(\mathrm{Co}_{3} \mathrm{O}_{4}\right.$ nanoparticle, $\alpha-\mathrm{Fe}_{2} \mathrm{O}_{3}$ nanorod, $\mathrm{NiO}$ nanoparticle $)^{26)}$ or peroxalate CL (bis $(2,4,6$-trichlorophenyl) oxalate in the presence of rubrene and imidazole) ${ }^{27)}$, this CL method should achieve an approximately 20 -fold increase in sensitivity.

\section{Conclusion}

Acridinium ester derivatives with electron-withdrawing groups at the 4-position in the phenyl ester were synthe- 
sized, the optimal $\mathrm{pH}$ values shifted from neutral conditions to alkaline conditions by introducing methyl groups at the 2-, 2,7-, and 2,3,6,7-positions on the acridine moiety. These acridinium ester derivatives can determine hydrogen peroxide concentrations under optimal conditions. Facile methyl substitutions apparently changed the CL intensities at different $\mathrm{pH}$ values. Moreover, acridinium ester derivatives having long-lasting CL under alkaline conditions were developed. These experimental results could be crucial information for the molecular design of useful acridinium ester derivatives at $\mathrm{pH} 7-10$.

\section{Author Contributions}

Manabu Nakazono: designed research, performed research, analyzed data, wrote the manuscript, funding acquisition. Shinkoh Nanbu: supervision. Takeyuki Akita: supervision. Kenji Hamase: supervision, funding acquisition.

\section{Acknowledgements}

This work was financially supported by the Kakihara Science and Technology Research Foundation (Grant No. 2-9-1). This work was the result of the use of research equipment shared in a MEXT Project for the promotion of the public utilization of advanced research infrastructure (Program supporting the introduction of the new sharing system, Grant No. JPMXS0422300120). We are grateful to Prof. Takashi Ito (Graduate School of Medical Sciences) and Prof. Satoshi Okada (Graduate School of Medical Sciences) at Kyushu University for detailed guidance for regarding the measurement of chemiluminescence spectra.

\section{Conflicts of Interest}

The authors declare no conflict interest.

\section{Supporting Information}

This material is available free of charge via the Internet at doi: 10.5650/jos.ess21186. ${ }^{1} \mathrm{H}$ NMR and ${ }^{13} \mathrm{C}$ NMR spectra of 1a-3d, chemiluminescence spectra, and standard curves of hydrogen peroxide.

\section{References}

1) Teranishi, K.; Shimomura, O. Coelenterazine analogs as chemiluminescent probe for superoxide anion. Anal. Biochem. 249, 37-43(1997).
2) Shimomura, O.; Wu, C.; Murai, A.; Nakamura, H. Evaluation of five imidazopyradinone-type chemiluminescent superoxide probes and their application to the measurement of superoxide anion generated by listeria monocytogenes. Anal. Biochem. 258, 230-235 (1998).

3) Kricka, L.J.; Voyta, J.C.; Bronstein, I. Chemiluminescent methods for detecting and quantitating enzyme activity. Methods Enzymol. 305, 370-390 (2000).

4) Roda, A.; Pasini, P.; Mirasoli, M.; Michelini, E.; Guardigli, M. Biotechnological applications of bioluminescence and chemiluminescence. Trends Biotechnol. 22, 295-303 (2004).

5) Griesbeck, A.G.; Díaz-Miara, Y.; Fichtler, R.; Jacobi von Wangelin, A.; Pérez-Ruiz, R.; Sampedro, D. Steric enhancement of the chemiluminescence of luminols. Chem. Eur. J. 21, 9975-9979 (2015).

6) Mayer, M.; Takegami, S.; Neumeier, M.; Rink, S.; Jacobi von Wangelin, A. et al. Electrochemiluminescence bioassays with a water-soluble luminol derivative can outperform fluorescence assays. Angew. Chem. Int. Ed. 57, 408-411 (2018).

7) Geiselhart, C.M.; Mutlu, H.; Barner-Kowollik, C. Prevent or cure-The unprecedented need for self-reporting materials. Angew. Chem. Int. Ed. 60, 17290$17313(2021)$.

8) McCapra, F.; Richardson, D.G.; Chang, Y.C. Chemiluminescence involving peroxide decompositions. Photochem. Photobiol. 4, 1111-1121 (1965).

9) Nelson, N.C.; Cheikh, A.B.; Matsuda, E.; Becker, M.M. Simultaneous detection of multiple nucleic acid targets in a homogeneous format. Biochemistry 35, 8429-8438(1996).

10) Sato, N. Synthesis and properties of new luminescent 10-carboxymethylacridinium derivatives. Tetrahedron Lett. 37, 8519-8522 (1996).

11) Dodeigne, C.; Thunus, L.; Lejeune, R. Chemiluminescence as diagnostic tool. A review. Talanta 51, 415439 (2000).

12) Browne, K.A.; Deheyn, D.D.; El-Hiti, G.A.; Smith, K.; Weeks, I. Simultaneous quantification of multiple nucleic acid targets using chemiluminescent probes. $J$. Am. Chem. Soc. 133, 14637-14648(2011).

13) Natrajan, A.; Wen, D. Effect of branching in remote substituents on light emission and stability of chemiluminescent acridinium esters. RSC Adv. 4, 2185221863(2014).

14) Han, Z.; Li, F.; Shu, J.; Gao, L.; Liu, X.; Cui, H. Acridinium ester-functionalized carbon nanomaterials: General synthesis strategy and outstanding chemiluminescence. ACS Appl. Mater. Interfaces 8, 17454-17460 (2016).

15) Yakovleva, J.; Davidsson, R.; Lobanova, A.; Bengtsson, M.; Eremin, S.; Laurell, T.; Emneus, J. Microfluidic en- 
zyme immunoassay using silicon microchip with immobilized antibodies and chemiluminescence detection. Anal. Chem. 74, 2994-3004(2002).

16) Magliulo, M.; Roda, B.; Zattoni, A.; Michelini, E.; Luciani, M.; Lelli, R.; Reschiglian, P.; Roda, A. An innovative, flow assisted, noncompetitive chemiluminescent immunoassay for the detection of pathogenic bacteria. Clin. Chem. 52, 2151-2155(2006).

17) Arakawa, H.; Tsuruoka, K.; Ohno, K.; Tajima, N.; Nagano, H. Development of a highly sensitive chemiluminescent assay for hydrogen peroxide under neutral conditions using acridinium ester and its application to an enzyme immunoassay. Luminescence 29, 374$377(2014)$

18) Xu, L.; Cao, Z.; Ma, R.; Wang, Z.; Qin, Q.; Liu, E.; Su, B. Visualization of latent fingermarks by enhanced chemiluminescence immunoassay and pattern recognition. Anal. Chem. 91, 12859-12865 (2019).

19) Nakazono, M.; Oshikawa, Y.; Nakamura, M.; Kubota, H.; Nanbu, S. Strongly chemiluminescent acridinium esters under neutral conditions: Synthesis, properties, determination, and theoretical study. J. Org. Chem. 82, 2450-2461 (2017).

20) Nakazono, M.; Nanbu, S.; Akita, T.; Hamase, K. Synthesis, chemiluminescence, and application of 2,4-disubstituted phenyl 10-methyl-10 $\lambda^{4}$-acridine-9-carboxylates. Dyes Pigm. 170, 107628(2019).

21) Nakazono, M.; Nanbu, S.; Akita, T.; Hamase, K. Chemiluminescence of methoxycarbonylphenyl 10-methyl-10 $\lambda^{4}-2,7$-disubstituted acridine-9-carboxylate derivatives. J. Photochem. Photobiol. A 403, 112851
(2020).

22) Razavi, Z.; McCapra, F. Stable and versatile active acridinium esters I. Luminescence 15, 239-244 (2000).

23) Razavi, Z.; McCapra, F. Stable and versatile active acridinium esters II. Luminescence 15, 245-249 (2000).

24) Wang, Z.; Liu, F.; Lu, C. Chemiluminescence flow biosensor for glucose using $\mathrm{Mg}-\mathrm{Al}$ carbonate layered double hydroxides as catalysts and buffer solutions. Biosens. Bioelectron. 38, 284-288 (2012).

25) Dong, S.; Liu, F.; Lu, C. Organo-modified hydrotalcitequantum dot nanocomposites as a novel chemiluminescence resonance energy transfer probe. Anal. Chem. 85, 3363-3368(2013).

26) Li, X.; Zhang, Z.; Tao, L.; Gao, M. Sensitive and selective chemiluminescence assay for hydrogen peroxide in exhaled breath condensate using nanoparticlebased catalysis. Spectrochim. Acta A 107, 311-316 (2013).

27) Lebiga, E.; Fernandez, R.E.; Beskok, A. Confined chemiluminescence detection of nanomolar levels of $\mathrm{H}_{2} \mathrm{O}_{2}$ in a paper-plastic disposable microfluidic device using a smartphone. Analyst 140, 5006-5011 (2015).

CC BY-SA 4.0 (Attribution-ShareAlike 4.0 International). This license allows users to share and adapt an article, even commercially, as long as appropriate credit is given and the distribution of derivative works is under the same license as the original. That is, this license lets others copy, distribute, modify and reproduce the Article, provided the original source and Authors are credited under the same license as the original. 